\title{
4.8 Діалого-культурологічний проект освіти: вітчизняна локальність в глобальному контексті
}

Сучасна освіта як феномен поліфонічної культури в Україні становить єдність загальносвітового та національного начал. 3 одного боку, етнокультурна ідентифікація українського народу відбувається нині в контексті входження України в глобальний «інтердискурсивний дискурс» інформаційного суспільства 3 притаманною йому тенденцією до діалогу культур. 3 іншого боку, виклики міжкультурної освіти в Україні відчуваються особливо гостро, зважаючи на полікультурність національного життя, історично складену внаслідок прикордонного геополітичного положення нашої держави між Сходом i Заходом. Маргінальним культурам притаманне суперечливе поєднання аскези й містики, відкритості й закритості, космополітизму й етнографізму, ксенофобії і хворобливого плазування перед іноземним - протилежні умонастрої, що однаковою мірою походять від невміння вести справжній діалог. Більш того: українська полікультурність, зрештою, зводиться до світоглядного дуалізму відкритого чи прихованого протистояння традиціоналістських впливів на Сході і Півдні та неоліберальних впливів на Заході. Просторова модель даного протистояння надає йому додаткової духовної напруги і сприяє формуванню свого роду «міфологічної географії» «своїх» $\mathrm{i}$ «чужих», «космосу» $\mathrm{i}$ «хаосу», «правильного світу» та «світу навиворіт», який залишається свого роду Чужим, монстром, «річчю в собі», джерелом табу, страхів і забобонів.

На специфіку духовного життя в Україні впливає також світоглядна ситуація, утворена у пострадянському просторі. Ідеологічна ніша, що «оголилася» внаслідок відмови від радянської ідеології, потребує свого заповнення, що провокує інтенсивні світоглядні експерименти. Їх учасниками $\epsilon$ представники різних поглядів і культур: від православної консервативної до католицької і постмодерної, що однаковою мірою номінують утворений вакуум у символічній структуру соціуму. На цьому тлі активізується освітня діяльність, яка у контексті парадигми універсальної етики та етики Іншого, філософії діалогу та гуманістичної педагогіки та на підставі конституційного принципу 
THEORETICAL FOUNDATIONS OF THE FUNCTIONING OF EDUCATION. WAYS TO

IMPROVE THE EFFECTIVENESS OF EDUCATIONAL ACTIVITIES

свободи совісті повинна виконувати миротворчу функцію щодо конфлікту східних і західних інтенцій через феноменологічний дискурс неупередженої академічної науки.

На наш погляд, зазначені вище опозиції східного і західного начал $є$ умовними і штучними. Їх необхідно подолати заради запобігання численних релігійних, політичних та світоглядних конфліктів. Питання полягає у тому, якими є конкретні механізми, програми освіти, які допомогли б «вилікувати» чи, принаймні, «притлумити» найбільш больові зони та базові травми нашої культури. Таким, на нашу думку, постає розроблений нами авторський кейс діалого-культурологічний проект навчання. Прикметник «діалогокультурологічний» складається із двох компонентів: «діалогічний» ma «культурологічний». Це вказує на апеляцію пропонованого концептуального підходу одразу до двох проблемних сфер: до філософії діалогу як до парадигми гуманітарного знання та до культурології як до інтегративної гуманітарної науки. Стосовно культурології філософія діалогу виконую функцію одного із провідних іiі методологічних напрямів, який передбачає інтерпретацію культури як буття Іншого, простору багатовимірної взаємодії культур. Відтак, маємо справу з філософією діалогу як культурологічною проблемою, переломленою крізь освітню «призму».

У даній роботі ми на підставі власних культурологічних досліджень, методологічно зорієнтованих на історизм, феноменологію, герменевтику та діалогістику, та на основі багаторічної педагогічної практики зробимо спробу визначити теоретично-методологічні засади та змістові складові діалогокультурологічного проекту навчання у межах сучасної вищзої та середньої освіти в Украӥні. Задля реалізації поставленої мети розглянемо наступні питання:

1. Аналіз основних проблем та провідних тенденцій розвитку освіти в сучасній Україні та у світі на прикладі виокремлення домінуючих світогляднометодологічних підходів до викладання і навчання гуманітарних знань (дані підходи класифіковані нами як «модерні» та «постмодерні»). 
THEORETICAL FOUNDATIONS OF THE FUNCTIONING OF EDUCATION. WAYS TO IMPROVE THE EFFECTIVENESS OF EDUCATIONAL ACTIVITIES

2. Розкриття конц̧епціiі діалого-культурологічного проекту як компромісного шляху у протистоянні наявних освітніх підходів (через уведення категорій «активної толерантності» та філософії діалогу як філософії Третього);

3. Окреслення перспектив практичного впровадження діалогокультурологічного проекту навчання в сучасну систему національної освіти (через окреслення ідеальної моделі освіченої людини у межах пропонованого проекту; виокремлення основних позицій методологічної та методичної новизни проекту та надання практичних рекомендацій на прикладі викладання авторських академічних курсів).

3 певними застереженнями можемо говорити про кризовий (або наближений до такого) стан освітнього прочесу в Україні. Головною причиною кризи є проблема методологічного зяяння у семіосфері освіти, яке дедалі поглиблюється завдяки відсутності в теоретичному та ментальному полі виховання відповідних духові епохи (i водночас не кон'юнктурних) концептуальних засад інтерпретації навчального матеріалу (або ж навіть відсутності самого усвідомлення необхідності вироблення таких знань i упровадження в навчально-виховний процес).

У науковому контексті сучасні методологічні засади викладання гуманістики постають як вияви відповідних теоретичних позицій (традиціоналізм, лібералізм, історизм, марксизм, екзистенціалізм, психоаналіз, феноменологія, герменевтика тощо). Якщо подивитися на ці методології чисто із світоглядної точки зору, можна редукувати їх багатоманітність до смислової опозиції двох найвпливовіших на сьогодні ціннісно-смислових установок, активно обговорюваних на форумах у Давосі та Порту-Алегрі. Мова йде про установки модерну $i$ постмодерну, які фіксують дві протилежні моделі філософування та, ширше, культурної екзистенції суб’єкта: їх дихотомію можна репрезентувати у формі опозицій універсалізм (модерн) - партикуляризм (постмодерн), або: фундаменталізм - релятивізм, ессенцііалізм екзистенцуіалізм [1, с. 311$]$. 
THEORETICAL FOUNDATIONS OF THE FUNCTIONING OF EDUCATION. WAYS TO IMPROVE THE EFFECTIVENESS OF EDUCATIONAL ACTIVITIES

Головна феноменологічна відмінність універсалізму (до якого тяжіють класичний лібералізм, персоналізм, екзистенціалізм, фрейдомарксизм, етика діалогу) від партикуляризму (до якого схильні неолібералізм i мультикультуралізм, традиціоналізм, консерватизм) полягає у спробі (для модерну) або утриманні (для постмодерну) від розв’язання фундаментальних проблем сутнісних основ явищ,, або метанаррацій, наприклад, питання про буття Абсолюту, сенс людського існування, єдність людства, наявність чи відсутність універсалій культури як спільних загальних витоків культурно-історичного процесу тощо. Якщо модерн тяжіє до позитивного розв'язання трансцендентальних проблем, виявляючи тим самим схильність до «проникнення у сутність», позитивної онтології, у версіях сакральної метафізики або світської (ідеалістичної чи матеріалістичної) діалектики, до виявлення причин явищ і тотального узагальнення законів їх розвитку та функціонування, то постмодерн як механізм ритуального самовідтворення модерну в умовах його кризи, з притаманним для нього іронічним прагненням до ковзання поверхнею (ризомою), звільняється від будь-яких метафізичних апеляцій, спрямовуючи свої деконструкції буття на іманентні категорії гри, випадку, ситуативності, плюральності, сліду, знаку, «мему», медіа-вірусу.

Наведений нами дискурс філософської дискусії складає світоглядне тло розвитку сучасної освіти в Україні. Серед тенденцій цього розвитку можемо виділити модерні (універсалістські) та постмодерні (партикуляристські), які формують відповідні концептуальні підходи до навчання. Модерні підходи тяжіють до апріорних метафізичних оціночних установок при визначенні культури. Дана категорія інтерпретується як онтологічне поняття, спрямоване на пошук самототожності, метафізичної ідентичності, сутності, самості, пам'яті, безперервності, походження, цүілісності існування, його витоків у вигляді універсалій та архетипів; розкриваються також проблеми сакрального досвіду у світській культурі, проблеми також Абсолюту, надприродного, Бога, постнаукової метафізики, істини. Причому істинність чи хибність розглядаються тут не як суто гносеологічні, а як буттєві категорії. На грунті позитивної онтології 
THEORETICAL FOUNDATIONS OF THE FUNCTIONING OF EDUCATION. WAYS TO IMPROVE THE EFFECTIVENESS OF EDUCATIONAL ACTIVITIES

освіта зближається з представниками богословсько-теологічного та атеїстичного напрямів, які однаковою мірою абсолютизують базовий характер духовного чи матеріального начал у якості антиномії. На рівні середньої шкільної освіти буттєва присутність богословсько-теологічного та світського підходів викликає дискусію про запровадження у школи, відповідно, або курсу релігійної етики, або курсу світської (академічної) етики. Перший варіант ускладнюється конфесійним розмаїттям нашої держави, а другий - погрожує перетворенню нейтрального «просвітницького» духу навчання у відверту атеїстичну пропаганду в стилі радянських стереотипів.

Постмодерний або близький до нього спосіб подолання тупикової ситуації пропонує феноменологічна школа, яка, спираючись на традиційний прийом ероhе Е. Гуссерля пропонує відмовитися від будь-яких оціночних суджень щодо метанаррацій, зупинитися, утриматися, подібно до Будди в стані золотого мовчання, від постановки і розв’язання метафізичних проблем, обмежившись сферою описового неупередженого розгляду інтенціональної спрямованості свідомості на предмет. Так, антиномічні кантівські запитання про Бога, добро, істину, красу, справедливість, рівність, ієрархію, свободу замінюються на дескриптивні практики окреслення того, як ми їх сприймаємо. На феноменологічний позиціях Україні часто стоять представники молодшого покоління освітніх діячів. Абстрагуючись від постановки невластивих для компетенції науки завдань, обмежуючись характеристикою конкретної багатоманітності культурного досвіду, феноменологи змінюють рух наукової думки 3 індуктивного на дедуктивний, 3 абстрактного на конкретний, iз загального на спеціалізований, з теоретичного на прикладний. Незважаючи на величезну роль феноменології у розвитку «чистої», «нейтральної», гуманістики, яке може запобігти численним конфліктам на грунті премордіального, представники феноменологічного напряму нерідко піддаються звинуваченням 3 боку своїх класичних академічних опонентів у позбавленні науки та навчання «світоглядної глибини», редукуванні його до еклектичного, фактографічного, ілюстративного, констатаційного підходу, що, таким чином, не тільки не сприяє 
THEORETICAL FOUNDATIONS OF THE FUNCTIONING OF EDUCATION. WAYS TO IMPROVE THE EFFECTIVENESS OF EDUCATIONAL ACTIVITIES

діалогу культур, але й унеможливлює його, оскільки спустошує комунікацію, редукуючи іiі до ввічливої, «люб'язної» бесіди по законах пасивної толерантності, позбавляє спілкування глибинних, екзистенційних смислів, взаємопроникнення яких складає справжню суть діалогу як взаємного руху Логосів.

Одним iз найбільш важливих аспектів протистояння модерного та постмодерного типів навчання є славнозвісна дискусія про універсалї, яка має ще середньовічні витоки. Чи існують поняття, цінності, які можна охарактеризувати як загальнолюдські? Чи, можливо, кожній із культурних традицій притаманний свій набір універсалій? У контексті даної дилеми модерн, орієнтуючись на «платонівсько-кантівський канон», позитивно відповідає на це запитання: так існують, і на цій підставі можна здійснити світовий синтез культур. Крайні вияви універсалізму тягнуть за собою небезпеку стандартизації, уніфікації, масовізації, центрації, тобто зосередження навколо єдиної панівної культури (європоцентризм, соціоцентризм, логоцентризм, «фалологоцентризм»), відносно якої інші культурні традиції піддаються ієрархічному лінійно-еволюційному ранжуванню на «модернізовані» та «відсталі», утворюючи матрицю прогресу, що більше нагадує глобалістичну колонізацію.

Постмодерн, на противагу, модерну, дотримується партикуляризму i оголошує установку на одиничне й особливе в кожній із множинних культур. Так, антикантіанець і постструктураліст Р. Рорті, представник нового прагматизму, стверджував, що «немає нічого в глибині кожного з нас, ніякої загальнолюдської природи, ніякої притаманної людству солідарності, яку можна було б використати для морального посилання» [275, с. 311]. Відповідно, універсалістська ідея синтезу розцінюється з боку східних культур як прихована реалізація західного (християнського) імпульсу через штучний пошук прозахідних елементів в абсолютно інших культурах світу. Фундаменталістський вибух на Сході довів неможливість такого синтезу, i наукова громадськість спрямувала свою думку в бік деконструктивістського 
THEORETICAL FOUNDATIONS OF THE FUNCTIONING OF EDUCATION. WAYS TO IMPROVE THE EFFECTIVENESS OF EDUCATIONAL ACTIVITIES

загострення відмінностей, вираженого у відомому афоризмі Р. Кіплінга про Захід і Схід, яким ніколи не зійтися [276].

Наслідки такого відношення - не менш (якщо не більш) болючі, ніж тотальна уніфікація. Надмірний релятивізм призводить відчуження, втрати цінностей, краху переконань, розчинення «Я» в Іншому, дистанціювання атомарних індивідів, нівеляції їх самості, тенозофобії та реваншизму. Толерантність у межах пасивного релятивізму завжди носить характер негативної, індиферентної толерантності, перверзивної лояльності, що спричинює кризу етнічної, культурної, релігійної ідентичності.

У результаті гуманітарна думка опиняється перед уявним бінарним вибором між двома крайнощами однієї сутності, а освіта як піi дзеркало коливається між тяжінням до чистої метафізики аксіологічної одержимості буттям або до іронічної феноменології руйнації його структури, коливаючись від статики до динаміки, від синтагми до парадигми, від синхронії до діахронії, від структури до історії. Від цих суперечок (часто - номінальних) страждає найбільшою мірою молодь, представники якої, виховані у сім’ях з різними світоглядними орієнтаціями, опиняються поруч у межах одного навчального колективу. Автор даної статті нерідко відчуває неминучі складності при читанні лекцій 3 культурологічних дисциплін, побоюючись, 3 одного боку» своєю універсалістичною «традиційністю» образити переконання постмодерних ліберальних іроніків, а 3 іншого боку, своїм релятивізмом (доля якого феноменологічно необхідна науці та освіті для підтримки належного рівня критицизму) образити консерваторів та аксіологів. Необхідно пам’ятати, що у реальній живій практиці культурного переживання буття молодь нерідко виявляється мудрішою за своїх наставників. Через безпосередні симпатії і прихильності, через імпровізаційне щирого спілкування нею інтуїтивно прокладаються ті шляхи, які передвіщають новий тип освіти і навчання.

Конфлікт універсалістичного та партикуляристського підходів в гуманітарному дискурсі інтуїтивно підводить нас до думки про певну «третю альтернативу», - не модерну i не посмодерну, але альтермодерну, - яка 
THEORETICAL FOUNDATIONS OF THE FUNCTIONING OF EDUCATION. WAYS TO IMPROVE THE EFFECTIVENESS OF EDUCATIONAL ACTIVITIES

пропонувала б «золотий серединний шлях» розв’язання проблеми. Яким чином зберегти відчуття єдності людства, яке сприяє міжнародному миру, і при цьому не стандартизувати своє існування? Як сприйняти ідею культурної множинності і при цьому не розчинитися у ній, не втратити власної ідентичності? Яким чином «обійти» болючі та інтимні питання особистих ціннісних переконань і при цьому не позбавити навчання екзістенційно глибини, не перетворити його на сухий ілюстраційний та конституційний опис фактів, коли викладач, втрачаючи духовну мужність артикуляції позиції, стає абстрактною «цифрою», віртуальним придатком, сервісом вічного карантину почуттів? Виникає асоціація 3 розумінням «золотої середини» у коанах дзен, коли остання не є консенсус (рікою між берегами), а є радикальним розривом з обома полюсами ілюзорного вибору (відсутністю берегів).

Такою сучасною «відсутністю берегів» постає, на нашу думку, діалогокультурологічний проект освіти. Головною конщептуальною засадою даного проекту є ідея активної толерантності. Щоб краще пояснити іiі сутність, звернемося до методологічних розробок сучасної герменевтичної критики. Для цього будемо застосовувати означники для двох виявів толерантності: «nacuвна» та «активна». В основу даного поділу кладеться ідея любові як універсальної духовної активності - поваги до Іншого, що виражається в здатності жертовно діяти заради нього (а не просто «терпіти» його присутність). У межах активної (дієвої) та пасивної (бездіяльної) толерантності по-різному розв'язується питання принц̧иповості як основи автентичності. Справжня, активна, жертовна толерантність не тільки не суперечить принциповості, але, навпаки, сприяє іiі розвитку. Активна толерантність не змішує саме переконання з агресією переконання: вона може протестувати проти ортодоксальності, але не торкатися принциповості. Бути толерантним за таких умов означає сповідувати власні переконання, але при цььому не нав'язувати їх Іншому. Відмінності між мною та Іншим не перебільиуються, але й не применшуються: вони втрачають своє абсолютне деструктивне значенням перед обличчям того спільного, щзо нас поєднує, - універсальної етики реальної любові. 
THEORETICAL FOUNDATIONS OF THE FUNCTIONING OF EDUCATION. WAYS TO

IMPROVE THE EFFECTIVENESS OF EDUCATIONAL ACTIVITIES

Утриматися на хиткій межі між активною та пасивною толерантністю надзвичайно важко. Активній толерантності постійно загрожує небезпека виродження $\quad$ у толерантність пасивну. Усвідомлення плюральності і релятивності думок може призвести до деградації щирої жертовної поваги у легковажно-зневажливу лояльність, поверховість, дистанційовану індиферентність щодо Іншого i, зрештою, безпринцинність. Небезпека такої деградації криється у формально-логічному підході до розв'язання проблеми: визнання за Іншим свободи мати і висловлювати власні переконання означає або поблажливо-зневажливе, снобістське визнання його права на помилку (виходячи 3 апріорної передумови, що мої переконання - «істинні», а переконання Іншого - «хибні»), або визнання його права на істину, але, якщо ми визнаємо, що Інший - правий, то ми можемо припустити, що помиляємося ми, виходячи з іманентно притаманної для європейської культури аристотелівської логіки опозицій. Підключення сюди східної релятивної логіки (у дусі силогізмів «А $\epsilon \mathrm{B} »-« \mathrm{~A}$ не $\epsilon \mathrm{B} »,-« \mathrm{~A} \epsilon \mathrm{B}$ і не $\epsilon$ В одночасно») створює враження, що правi-yci, що «істин» - багато, що вони є відносними і контекстними (залежними від конкретних умов «вживання», а відтак - однобічними i, якщо взяти кожну із них окремо, недосконалими, оскільки Захід, на відміну від Сходу сприймає релятивізм як шлях до порожнечі, зяяння, а Схід наповнює порожнечу онтологічним змістом непізнаваної сутності - шуньяти). 3 цього приводу згадаємо міркування П. Рікера щодо «корозії» толерантності, метаморфози іiі гуманістичної сутності в егоїстичну установку, відповідно до якої «все варте й ніщо не варте того, щоб зобов'язувати нас» [277, с. 325].

Відтак, плюральність (хаотична множинність) породжує плюралізм (легалізацію множинності у нормативний принцип), який, у свою чергу, призводить до культурного релятивізму (усвідомлення відносності множинного) $i$ нісілізму (заперечення множинного і відносного). Звідси - ціла низка релятивних станів атомарного суб'єкта постмодерну: відчуження" самотність, абсурд, онтологічна нудьга", криза метафізичної ідентичності, травма, зяяння. Розмивається архетипний образ Істини як Цілого і Єдиного. 
THEORETICAL FOUNDATIONS OF THE FUNCTIONING OF EDUCATION. WAYS TO IMPROVE THE EFFECTIVENESS OF EDUCATIONAL ACTIVITIES

Яким чином подолати кризову ситуацію? Необхідно певним чином поєднати сприйняття і переживання багатоманітності культурних позицій 3 відчуттям їх внутрішньої єдності, усвідомлення наявності багатьох точок зору й одночасне прагнення до правди Цілого. Для цього потрібно представити ці точки зору як конкретні (однаково досконалі, але й однаково обмежені) вияви єдиної істини у різних її варіаціях та версіях, що відображають їі різні грані і при цьому тільки через взаємодію (діалог) можуть дати повну і цілісну картину дійсності. Отже, потрібно знайти спільний базис культурних протистоянь, який перетворює їх на альтернативні, але все ж таки часткові інтерпретації загального, виносячи за дужки руйнівні відмінності, але зберігаючи екзистенційно важливі самобутність і оригінальність кожного. Цим базисом, власне, і постає філософія діалогу як філософія Третього - Закону, мета-позиції, «Другого Іншого», тексту, посередника між Автором і Читачем, духу, про який говорив М. М. Бахтін [278, c. 293].

Третій - це спільний суддя учасників суперечки, який відіграє роль єдиної точки опори у плюральному протистоянні. Саме Третій окреслює межі толерантності, накладає ліміт на інерцію розгортання релятивізму. Третій сприяє формуванню активної толерантності на основі пасивної або попереджає iii деградацію, утримуючи їі в активному стані, не дозволяючи альтруїстичному переживанню світу перерости в індиферентну лояльність. Третій дозволяє повернутися до ідеалу абсолютних цінностей, групуючи навколо їх «вісі» взаємодію численних трактовок. Тим самим Третій запобігає кризі ідентичності і відіграє ключову роль у формуванні методологічних засад науки, культури, освіти та, зокрема, діалого-культурологічного проекту освіти. Зрештою, уся філософія діалогу у сучасному дискурсі може бути прочитана як філософія Третього між «Я» та Іншим, що перетворює їх на нерозривне і незілляне «Ми».

Водночас існує архетипічний бар’єр у спілкуванні, який заважає появі Третього. Очевидна потреба в Іншому стикається 3 життєстійкістю етнічних архетипів, ядро яких складає міфологічний поділ Всесвіту на дві нерівні за цінністю і якістю сфери: «вищу», яка асоціюється із свойми як носіями 
THEORETICAL FOUNDATIONS OF THE FUNCTIONING OF EDUCATION. WAYS TO IMPROVE THE EFFECTIVENESS OF EDUCATIONAL ACTIVITIES

культурних цінностей, та «нижчу», де мешкають чужі як «дикуни» і «варвари». Звідси - комплекси ксенофобії, реваншизму, расизму, моноетніцизму тощо. Культура етноцетричного типу спирається на розширене знання власних цінностей, яке, грунтуючись на емоційно-чуттєвій сфері, затьмарює для неї інші культури, формує їх образи відповідно до своїх фантазмів, страхів, забобонів та редукційних стереотипів - вульгаризованих зведень усієї внутрішньої багатоманітності і суперечливості кожної культурної традиції до певних крайніх, видимих переважно профанній аудиторії, знаково-символічних форм, панівних непроникних означників, що уявляються їй джерелом небезпеки, хаосу, агресії.

Як це не парадоксально, Третій відкривається у момент, коли напруження між культурами досягає апогею, і непроникна «гладкість» їх символічних форм дає тріщину, загрожує розірватися під впливом короткого семітичного змикання, коли крізь символічні означники прориваються реальність і роздирає «шви» між означниками та означуваними. Поява Третього є до певної міри неминучою. Вона випливає із пізнання людиною Чужого, але пізнання особливого, яке можливе лише за рахунок герменевтичної інтерпретації його внутрішнього світу як тексту, щзо піддається дешифровці, де|кодуванню, деконструкиї. Конфліктна ситуація, яка виникає між учасниками діалогу, тільки збільшує глибину проникнення в Іншого. Адже в умовах «Виклику»у міжкультурний континуум виходять гени-архетипи культури, які чекають на свою «Відповідь». Виникає суперечлива ситуація ідентифікацію 3 Тінню: діалог культур найефективніше відбувається в умовах протистояння свідомостей їх носїв, коли суб'єктивні ставлення не можуть зупинити процес об'єктивних запозичень. Свідомість-текст Іншого лежить перед своїм інтерпретатором, який повинен, використовуючи ресурси асоціативної пам'яті i творчої уяви проникнути через емпатію та співпереживання у цей текст та зрозуміти його прихований смисл - настільки, наскільки допускає цього сам Автор тексту i навіть і більше - зрозуміти як Реальне. Для цього потрібно уміти ставити себе на місце Іншого, тобто - вступити в процесі рефлексї у внутрішній діалог. Таке уміння особливо важливим постає для людей творчих професій (митців, 
письменників, педагогів), у яких діалог, спілкування, комунікація, порівняння себе з Іншим - читачем, глядачем, слухачем, учнем - постає основою фахової діяльності. Ще О. Мандельштам наголошував, що поет повинен прориватися до «провіденщійного співбесідника», який є невід’ємною передумовою творчого самовираження автора: «Немає лірики без діалога. - пише О. Мандельштам. - А єдине, що штовхає нас в обійми співбесідника, - це бажання здивуватися своїм власним словам, полонитися їх новизною і неочікуваністю» [5, с. 174]: немає без діалогу і педагогіки, бо за суттю вона теж є поезією спілкування.

Так народжується спільна «дитина» у діалозі «Я» та Іншого - Третій, який трансформує Хаос Чужинця на Космос, Ворога - на Друга, - хай і незбагненного, але нагально необхідного для «мого» внутрішнього виживання. Третій одомашнює Чужого, надає йому знайомих культурних рис Іншого і Ближнього, робить його зрозуміліше, відкриває його як зворотну сторону «Я», яке завдяки усвідомленню нестачі Іншого осягає і власну травму. Завдяки діалектиці Третього Чужий перетворюється на Іншого, а Інший - на Ближнього. Функціональні повноваження Третього можна розділити по двох основних напрямах: соиіально-комунікативний та морально-етичний.. Перший стосується плюралістичного характеру суспільства, мультикультурної ситуації, у якій відбувається діалог культур. Образ Третього допомагає віднайти спільну нормативну точку опори за умов наявності множинних шляхів розвитку окремих культур. Другий напрям акцентує увагу на морально-етичному фокусі діалогу, який стягує воєдино його численні лінії перетину. Мова йде про ціннісне опосередкування діалогічного прочесу. Третій відіграє роль морально-етичного критерію, який сприяє розмежуванню конструктивних і деструктивних виявів культурної активності, виключаючи з поля діалогу вульгарні редукції культур. Відтак процес соціокультурної інтеграції у діалозі культур поєднується із процесом моральної селекиї.

Конщепт Третього - цілком педагогічний, діалогічний, етичний та культурологічний. Адже Третій - це, у першу, чергу, «універсалії культури»загальнокультурні інваріанти, що піддаються безлічі історичних та регіональних 
THEORETICAL FOUNDATIONS OF THE FUNCTIONING OF EDUCATION. WAYS TO IMPROVE THE EFFECTIVENESS OF EDUCATIONAL ACTIVITIES

інтерпретацій. Культурологія ж є інтегративною наукою про смисли культури, виражені у відповідних текстах, а педагогіка є способом виховання учня через культуру, вона має високий культурологічний потенціал, будучи формою здійснення трансляції культурної пам’яті. У цьому контексті концепт Третього та діалог як «взаємопроникнення смислів» за посередництва символічної іпостасі Третього постає спільною предметною основою культурології, педагогіки, філософії діалогу та етики Іншого одночасно.

Універсальні смисли культури потрібно сприймати як апріорну данicmb, оскільки наявність або відсутність їх не верифікується через позитивістські методи. У межах критичного бачення можемо говорити лише про умовні риси універсалій. Дані смисли є: екзистениійними, оскільки сягають глибинних духовних основ людського буття в його інтимно-трансцендентальному вимірі. Вони є трансперсональними (одухотвореними, але не особистісними), оскільки поєднують інтимну сингулярність 3 універсальністю людства; інтеркультурними (полегшують процес спілкування між культурами); кроскультурними («перетинають» культурні кордони) i водночас транскультурними (трансцендентними стосовно частковостей культурного простору і водночас іманентно притаманними внутрішньому світові кожного суб’єкту даного простору, - отож, можемо стверджувати їх транскультурність як «інтракультурність»). Найбільші труднощі полягають у спробі науково конкретизувати зміст універсальних смислів, буття яких виходить за межі раціоналістичного дискурсу. Хаос і космос, життя і смерть, чоловіче і жіноче, добро i зло, любов і ненависть, краса і потворність, істина i хиба, свобода i відповідальність, тривога і мужність, самотність і соборність, благо і шкода- ось неповний перелік «ликів» Третього.

В етиці поняттю універсалій відповідає категорія «загальнолюдські цุінності» як значущі для людства категорії високої моральні вартості. На рівні гносеології Третій - це Істина при багатоманітності пізнавальних підходів до неї. На рівні теологічного підходу Третій - це Бог при багатоманітності духовних шляхів до нього. У мистецьких діалогах Третій складає правду Цілого, яка, 
THEORETICAL FOUNDATIONS OF THE FUNCTIONING OF EDUCATION. WAYS TO IMPROVE THE EFFECTIVENESS OF EDUCATIONAL ACTIVITIES

будучи невисловленою, у формі невербального підтексту плаває у паузах між репліками (пригадаємо «принщ̧ип айсбергу» - прихованого змісту твору - в постулатах Е. Хемінгуея, Е.Р.М. Ремарка, А.П. Чехова, М. Цвєтаєвої, М. Басьо). Наявність «Третього» формує головний результат діалогу - почуття активної толерантності як універсальної духовної якості людини, яка через переживання своєї спільності 3 Іншим здатна до допомоги йому як Ближньому i до усвідомленого злиття двох нестач - своєї та Іншого - в любові.

Коли ми звертаємося до прикладних кейсів діалого-культурологічного проекту навчання, у першу чергу, постає запитання: що $є$ його кінцевим продуктом? Яким є ідеал освіченої людини в контексті діалогу культур? Збагнути його сутність видається надзвичайно важливим, адже цей новий тип релігійної особистості, як «Велике напередодні», є і досі уявним проектом, алгоритмом, розгортання якого кардинальним чином позначиться на долі культур. Чи буде ця людина майбутнього постмодерною «надлюдиною» у дусі Ф. Ніцше чи М. Фуко чи «вищою людиною» модерну, як того М. Гайдеггер та Ю. Габермас? Наразі можемо судити лише про окремі абриси світогляду діалого-культурологічної особистості. Очевидно, що це повинна бути особистість, що володіє здатністю віднаходити Третього у міжкультурному спілкуванні. Основою ï світогляду повинна стати культура діалогу (діалогічна свідомість) - відкритість світові різноманітних духовно-емоційних, ментальних, цивілізаційних, етнічних, конфесійних традицій, які пронизують внутрішній світ «людини культури» у якості їі інтеріорних складових та синхронно взаємодіють у ньому. Така людина повинна бути готова до емпатійного пізнання Іншого, поваги до нього, турботи про нього, відповідальності за нього і співпраці з ним на основі щирої, альтруїстичної зацікавленості чужими культурами, які стають органічною складовою іï власної самості, не відтинаючи при цьому сутнісно необхідні умови їі власної екзистенції. Традиційний партикуляризм у поліфонії культур за принципом матрьошки вкладається в модерний універсалізм єдності людства як поля міжкультурного діалогу. Діалог є формулою єдності у багатоманітності, погодження універсалізму з партикуляризмом. 
THEORETICAL FOUNDATIONS OF THE FUNCTIONING OF EDUCATION. WAYS TO IMPROVE THE EFFECTIVENESS OF EDUCATIONAL ACTIVITIES

Можемо говорити про три головні компетениії діалогічної свідомості нашого вихованця: культурологічна освіченість, сочіальна комунікативність $i$ активну толерантність. Перша риса - культурологічна освіченість - відбиває інформаційну евристичну компетенцію людини, iї обізнаність із фактом існування Чужого, не схожого на мене. Друга риса - соиіальна комунікативність - засвідчує уміння вступати у взаємодію з Чужим як з Іншим (дивним, але не ворожим сусідом). Третя риса - активна толерантність - вищий етап еволюції діалогічної свідомості до рівня любові - пов’язана із універсальною моральнодуховною компетенцією людини, іiі здатністю жертовно ставитися до Іншого як до Ближнього - у первинному, біблійному сенсі цього слова (співзвучну думку у контексті релігієзнавства висловлює бельгійський дослідник Б. Роббен, класифікуючи релігійну освіту на «мульти-, інтер- та інтрарелігійний» iї типи $[280$, c. 5-6]).

Різноманітні освітні технології в Україні мають великий досвід формування такої людини. Так, наприклад, в окремих навчальних закладах упроваджувалися методи «иколи діалогу культур» (експериментальної програми В. Біблера, яку застосовували Г. Балл, А. Волинець, В. Литовський, В. Возняк та інші); школи «особистісно орієнтованого навчання» («педагогічної майстерності» I. Зязюна). Водночас зазначені експериментальні майданчики, стосувалися, в основному, загальної середньої освіти, і наразі - їх недостатньо для формування високої комунікативної культури учня у плюральному соціумі. Нові методологічні та методичні кейси пропонованого нами діалогокультурологічного проекту навчання $€$ спробою заповнення зазначеного педагогічного вакууму та виявляються у таких позиціях: а) культурологічний підхід до філософії діалогу; б) проекція культурології діалогу на освіту; в) урахування негативних наслідків міжкультурного діалогу (криза ідентичності) та вироблення шляхів їх подолання (концепт Третього в діалозі); г) забезпечення спадковості діалогічного навчання у межах вищої та середньої освіти.

Перший кейс діалого-культурологічного проекту освіти: діалогічна гра. Даний проект грунтується на поєднанні філософії діалогу та культурологї через 
THEORETICAL FOUNDATIONS OF THE FUNCTIONING OF EDUCATION. WAYS TO IMPROVE THE EFFECTIVENESS OF EDUCATIONAL ACTIVITIES

семантичну трактовку діалогу культур як взаємодї̈ смислів. Якщо діалогічна філософія складає методологічний світоглядний аспект нашого проекту, то культурологічне знання складає його внутрішній навчальний зміст. У контексті діалого-культурологічного підходу вихованець перестає бути просто учнем чи студентом: він перетворюється у Творияя та Iнтерпретатора Тексту Культури, активного учасника смислових процесів, які відбуваються всередині іiі життєсвіту та всередині індивідуального духовного світу учня або студента.

Відтак, першоджерела, оригінальні тексти культури (а не лише тексти критики, коментарі другого, третього і т.д. порядків) стають живим змістом культурологічної освіти, а герменевтична інтерпретація як процедура діалогу із методу культурологічного дослідження перетворюються у метод навчання i виховання. Мова йде не тільки про різні типи уроків, лекцій та семінарських занять, але й про діалогічні заняття: наприклад, автор цього дослідження регулярно проводить із студентами студії-діалоги у формі рольової гри, темою якої є диспут «героїв» різних культур з приводу універсалій («сенс людського буття», «образ людини» тощо). Під час такої культурологічної гри студенти через інтерпретацію оригінального тексту культури «переймаються» світом обраної ними традиції і навчають мистецтву полеміки з іншими точками зору.

Другий кейс діалого-культурологічного проекту освіти: зближення сакрального та секулярного світоглядів. Даний проект має специфічну спрямованість на освіту як на простір діалогу релігійних та світських традицій. Ідея діалогу культур репрезентується через ідею взаємодї сакральних смислів даних культур, взятих у їх світському культурологічному розумінні $і$ навпаки: світські тексти інтерпретуються як приховано релігійні. Така кореляція дозволяє глибше осягнути архетипи культури, оскільки найбільш глибинні діалогічні «дотики» культур відбуваються саме у межах релігії. Крім того, синтез культурології, педагогіки, етики та релігієзнавства у межах даного проекту відповідає пріоритетним тенденціям до інтегращії гуманітарних наук, результатом якої є виникнення нових галузей знання, які складають основу відповідних університетських спеціальних курсів. Результатом нашої спроби 
THEORETICAL FOUNDATIONS OF THE FUNCTIONING OF EDUCATION. WAYS TO IMPROVE THE EFFECTIVENESS OF EDUCATIONAL ACTIVITIES

застосування культурологічної методології в релігієзнавстві та релігієзнавчого матеріалу в культурології є розроблені автором спеціальні курси для студентів спеціальностей «Культурологія» та «Релігієзнавство»: «Культура стародавніх цุивілізацій», «Типологія культур Сходу», «Культура і релігія», «Культурологічні проблеми релігійно-філософської думки», «Філософія Іншого та етика діалогу». Особливо важливим, з огляду на наш проект, є курс «Філософрія Іншого та етика діалогу», оскільки він вводить студентів одразу у теоретичний, етичний, ментальний, релігійний та культурологічний контекст парадигми Іншого i Третього), забезпечуючи базову світоглядну підготовку на активну толерантність. Цей курс допомагає вихованцю в умовах релятивізму та плюралізму подолати тіньовий «виворот» діалогу - втрату культурної ідентичності за допомогою залучення універсальної етики. Ключову роль у цьому відіграє концепт Третього як ключова категорія філософії діалогу, яка стає головною концептуальною засадою освітнього процесу.

Третій кейс діалого-культурологічного проекту освіти: спадковість освіти. Пропонований проект сприяє не лише діалогу культур, але й становленню продуктивної взаємодії середньої ma вищуої освіти через упровадження у загальноосвітніх школах адаптованих елементів зазначених академічних університетських курсів. На основі упровадження діалогокультурологічного проекту у вищій школі нами розроблено та затверджено МОН України оригінальний авторський інтегрований експериментальний факультативний курс “Розмаїття релігій $i$ культур світу”, що нині впроваджується в навчально-виховний процес в окремих середніх загальноосвітніх навчальних закладах. Курс призначений для учнів 1-12 класів та спроектований як альтернативний курсам секулярної та релігійної етики [7]. Мета курсу - компаративний аналіз різних типів культур на підставі спільних изінностей (універсалій): індо-буддійської, японо-буддійської, даоськоконфуціанської, арабо-мусульманської, християнської. У змісті курсу цей аналіз репрезентований як своєрідна співбесіда-перекличка різних голосів культури 3 універсальних проблем людства. 
THEORETICAL FOUNDATIONS OF THE FUNCTIONING OF EDUCATION. WAYS TO

IMPROVE THE EFFECTIVENESS OF EDUCATIONAL ACTIVITIES

Таким чином, діалог з Іншим, який веде учень або студент, завершується діалогом дорослої людини зі світом. Водночас у самому використанні дієслова «завершувати» щодо діалогу відчувається відверта итучність: справжній діалог ніколи не можна завериити - його можна лише перервати. Перервати після закінчення школи, щоб наразі розпочати знову у зрілому віці життя, занурюючись у глибини ціннісних спектрів Чужинця, який став Другом. Власне, саме така здатність визначає тип людини XXI ст. на межі модерну та постмодерну і виховується через евристичні, соиіально-комунікативні та морально-духовні компетенциї поступової еволюції свідомості вихованця від Чужсго через Іншого до Ближнього, від мови ненависті через мову активної толерантності до мови любові й солідарності.

Діалого-культурологічний проект навчання - це педагогічна розмова у стилі «нон-стоп» на грунті синтезу філософії, етики та культурологї в освіті, розмова, подібна до сократівського діалогу, де «любов до мудрості» (Philia Sophia) поста' як рух до горизонту істини, яка одночасно пізнавана та непізнавана, близька та далека, передує діалогу і наслідує його, творить суб'єкта як подія і твориться ним в історії культури. Можливо, це буде видаватися утопією, але, пригадаймо «Вірую, тому що абсурдно» Квінта Тертуліана - цю геніальну формулу глибинної «справжності», практично повторену в слогані студентів Сорбонни 1968 року: «Будьте реалістами, вимагайте неможливого». діалог є механізмом радикального розриву з прагматикою панівних означників. Його результатом постає одночасно нове і старе відкриття, оскільки традиція є інновацією за умов іiі нового переживання, а інновація - традицією за умов іiі номінації старими іменами. Людина відкриває у своєму індивідуальному мікрокосмі увесь макрокосм думок і почуттів людства і при цьому не втрачає власної ідентичності, тому що відчуває «свою-чужу» цілісність і самототожність.

Реалізуючи людство, така людина реалізує себе, і навпаки: реалізуючи себе, реалізує людство. «Возлюби ближнього свого», переломлене крізь кантівський категоричний моральний імператив і загартоване у постмодерних 
THEORETICAL FOUNDATIONS OF THE FUNCTIONING OF EDUCATION. WAYS TO

IMPROVE THE EFFECTIVENESS OF EDUCATIONAL ACTIVITIES

інтелектуальних битвах, - таким є остаточний девіз діалого-культурологічного проекту освіти. Щоб зрозуміти Іншого, потрібно залищатися Собою, - щзоб зрозуміти Себе, треба в самому собі стати Іншим. Можна заперечити: ідея діалогу, дійсно, не є новою, але просто відкладеною людством на полицю майбутнього пильною старою книгою, але «витіснене повертається». Воно повертається у новій інтерпретації Іншого через Третього, поєднуючи сакральний досвід традиції з універсальною етикою, а культурологічну гру - 3 онтологічною істиною.. 